\title{
A STUDY ON SOCIAL MEDIA USE TENDENCIES: THE CASE OF ERZINCAN BINNALI YILDIRIM UNIVERSITY
}

\author{
İran ERTEKIN \\ Siirt University, FEAS \\ irfan.ertekin@siirt.edu.tr \\ https://orcid.org/0000-0003-2443-8528
}

\begin{abstract}
Social media has an important place in the lives of university students as a new communication means. In this context, it is possible to argue that social media is the most important component of the lives of students. Social media is one of the most important elements of the new media. The tendencies of social media usage have become one of the most important parameters that affect the social lives of university students. The purpose of the present study was to determine whether gender, age, grades and department variables affected the tendencies of university students in using social media with data. The study was conducted face-to-face with 213 students, 142 of whom were female and 71 of whom were male. As a result of the study, it was determined that gender, age, and grade variables were effective on the tendencies of students in using social media; and the department they studied was not effective. The study is important in terms of determining the social media usage awareness of university students. Because it addresses the tendencies of university students in using social media from a different viewpoint. In this study, the extent to which demographic variables affected the social media use tendencies of university students was determined. The study is important in this respect.
\end{abstract}

Keywords: Social Media Use Tendencies, Communication, University Student, Variables.

\section{SOSYAL MEDYA KULLANIM EĞİLIMLERİ ÜZERINE BİR ARAŞTIRMA: ERZINCAN BINALİ YILDIRIM ÜNIVERSITESI ÖRNEĞİ}

\section{ÖZ}

Sosyal medya, yeni bir iletişim ortamı olarak üniversite öğrencilerinin yaşamlarında önemli yer tutmaktadır. Bu bağlamda, sosyal medyanın öğrencilerin yaşamlarının en önemli bileşeni olduğu ifade edilebilir. Sosyal medya, yeni medyanın en önemli unsurlarından birisidir. Sosyal medya kullanım eğilimleri, üniversite öğrencilerinin sosyal yaşamlarını etkileyen en önemli parametrelerden birisi haline gelmiştir. Araştırma, üniversite öğrencilerinin sosyal medyayı kullanım eğilimlerinde cinsiyet, yaş, öğrenim gördükleri sınıf düzeyleri ve bölüm değişkenlerinin etkili olup olmadığını verilerle ortaya koymak amacı ile yapılmıştır. Araştırma, 142'si kız ve 71'i erkek öğrenci olmak üzere toplam 213 öğrenci ile yüz yüze gerçekleştirilmiştir. Araştırma sonucunda, cinsiyet, yaş, sınıf düzeyi değişkenlerinin, öğrencilerin sosyal medya kullanım eğilimlerinde etkili olduğu, öğrenim gördükleri bölüm değişkeninin ise etkili olmadığı saptanmıştır. Araştırma, üniversite öğrencilerinin sosyal medya kullanım farkındalıklarının ortaya konulması açısından önemlidir. Çünkü, araştırma üniversite öğrencilerinin sosyal medya kullanım eğilimlerini farklı bir bakış açısıyla ele almaktadır. Araştırmada, demografik değişkenlerin hangi ölçüde üniversite öğrencilerinin sosyal medya kullanım eğilimlerini etkilediği elde edilen verilerle ortaya konulmuştur. Araştırma, bu yönüyle önem arz etmektedir.

Anahtar Kelimeler: Sosyal Medya Kullanım Ĕ̆ilimleri, İletişim, Üniversite Öğrencisi, Değişkenler. 


\section{INTRODUCTION}

In the first quarter of the $21^{\text {st }}$ Century we live, which is also called as the Digital Age and Design Age, new communication media developing at a fast pace. In other words, communication media are redesigned with the developing and renewing technological infrastructure, and serve millions of users. With the transition to internet technology, which was also called world wide web (www) towards 1990s, as McLuhan (Tutar and Y1lmaz, 2005: 309) stated, the world has became a global village. The globalization discourse came to the forefront depending on the accelerated neoliberal developments and the transition to free market economy, the emergence of new communication means all contributed to the emergence of technological communication means, which we may also call as "the new media". The "global village", which was first mentioned by McLuhan in 1964 in his book "Understanding the Media", was defined by McLuhan as "the term that tells us about the change and development undergone by the radio, television, and cinema as a result of irresistible cultural dissemination" (Yengin and Bayrak, 2018: 59). It is possible to claim that the above-mentioned new trends affected important paradigms like education, health, economy, finance etc. Aktan (2007) stated that the trends like population increase, globalization, information society, new basic technologies, state reforms, good management, increasing competition brought with them the new changes in underdeveloped and developing countries. In other words, the media discourse, which is extremely important in communication studies, in one sense, "evolved" and gained a new and massive dimension.

The new media has made significant progress under the leadership of social media. After 2004, social media applications began to increase. Therefore, social media and networking applications attracted the attention of the young population. The first quarter of the 21 st century was a period of other digital developments. Social media is still popular as a new and digital communication means that emerged in the first quarter of the 21st Century, which is also defined as the electronic, digital and design age, with Artificial Intelligence, automation, robot and robotic systems, etc. In this context, it is possible to argue that the "Usage and Satisfaction Model", which is one of the basic approaches of the traditional media research, is also a valid hypothetical model for social media research. Because when studies conducted on social media were reviewed, it was determined that mostly the "Usage and Satisfaction Model" of Katz was employed in studies (Ertekin, 2019: 388-389). Social media has an important place in the lives of university students as a new communication an media. Social media use tendencies have become one of the most important parameters affecting the lives of university students.

The communication process continued with mass communication means like radio, television, and newspaper, which we call the traditional media, and the social media tools (like Facebook, Twitter, Instagram, etc.) has begun to emerge as of 2004 as a result of the geopolitics, economic and technological developments, which are also called as the new media, established communication with the public opinion. Individuals act to be happy and successful. One of the most important factors making individuals happy is to exist in the society, and think as "I am a member of this society and a part of them". For this reason, they establish communicate to covey this perception to the other party. In the communication process, every feedback with positive and praising messages received by the receiver is one of the most important tools to be happy. As a matter of fact, social media keeps its upto-date position as a very popular communication tool with which individuals, namely users, tell themselves and give the message that they are present in society. According Smith and Zook (2011), individuals are able to get to know each other, express their needs develop relationships and cooperation through social media (Çetintaş, 2014: 2). According Hinton and Hjorth (2013), social media impacts on the way in which we think, experience and practice with online media. Social media keeps its popularity not only in the world but also in our country. In the "Digital in 2018 in Western Asia" Report that was prepared by "We Are Social and Hootsuite", it was stated about Turkey whose population was 81 million people that there were; 54.3 million Internet users that constitute $67 \%$ of the population, 51 million active social media users that constitute $51 \%$ of the population, 44 million active mobile social media users that constitute $54 \%$ of the population (Dijilopedi, 2018).

Submit Date: 10.04.2019, Acceptance Date: 17.06.2019, DOI NO: 10.7456/10904100/001 465

Research Article - This article was checked by Turnitin

Copyright (C) The Turkish Online Journal of Design, Art and Communication 


\section{SOCIAL MEDIA}

Year ago, aphorism was mentioned by Nicola Tesla (2015), and tells best the social media in which millions of users are in constant interaction with each other in a synchronous or nonsynchronous manner by singing up an account in the social media which hosts web 1.0, web 2.0, web 3.0, blog, wiki, wiki network, Facebook network, twitter network, which was also mentioned by McLuhan as a global village (2001). Social media is not only a communication medium in which individuals share their feelings, thoughts and comments, but it is a medium where new discourses are emerging today as a wide range of online products, services, institutions, organizations, companies, businesses, etc., and has become a communication means promoting marketing in economy where new discourses like postmodern marketing, image and emotional marketing, relational marketing (Kotler, 2010) have emerged. Accoding to Çetintaş (2014), social media is an environment for communicating with and maintaining customers. Social media is not just a channel where people can have knowledge and experience about products, services end the organization. Social media also allows customers to reach and influence them. This makes contributes positively to the interpretation and making sense of the institution and its brand. It may be claimed that it is an important digital communication tool in communicating with target masses for educational institutions, healthcare institutions, and tourism businesses outside their establishments.

According to Çetintaş (2014), social media is a broad term that is used to describe all types of contents like blogs and forum messages, images, audio, video, links, profiles and status updates that exist in social network sites, which constitute social networks. Therefore, social media has very rich content. Therefore, social media attracts the attention and attention of the users. One of the most prominent characteristics of these social media means is that nearly all provide us with high-level sharing services because they include different, new and fast technologies. (Kahraman, 2013: 21). In summary, social media is a new medium of communication. In this respect, social media is a platform where people share their feelings and thoughts.

\section{Social Media Means}

According to Ackland (2013), Web 1.0 websites; two organization (A and B) each have a web site. The webmaster for organization A creates a hyperlink from a webpage on his organization's website to a webpage on the website of organization B.

Hyperlink from A's website

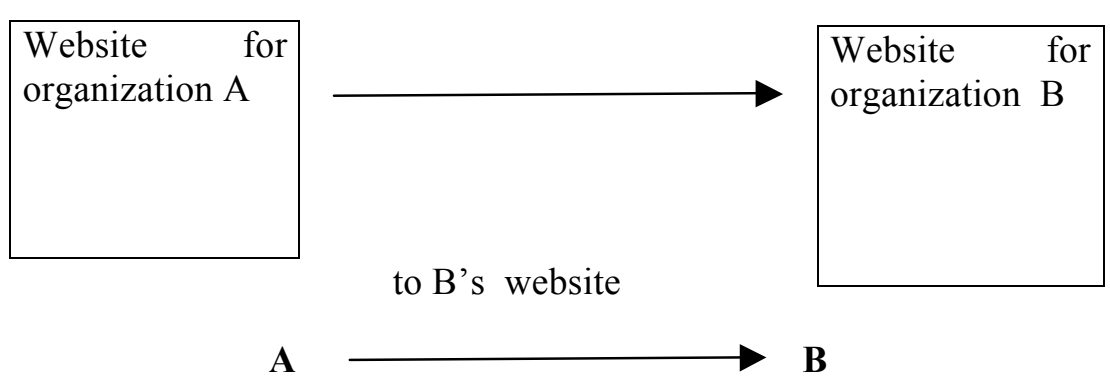

Figure 1. Web 1.0 Network (Ackland, 2013)

The definition of the blog can be made as follows. Blogs are online magazines where people add content they want (Çetintaş, 2014: 84). Blog can actually be described as weblog. Accorging to Kahraman (2013), The weblog concept, which was derived by joining the web and log terms, and which refers to a web diary, has become referred to as blog in time. Blog is a website where content is uploaded in the same system. In other words, blogs provide a symmetrical process. Wikies are a type 
of online websites where many users share their content. Especially scientists and writers prefer wikies. Because the wiki is a platform for them.

Social media can be defined as the use of a social network. Uses of social networking are quite varied. Vural and Bat (2010) stated social networks as follows; Social networks generally include the following elements; Social websites: myspace, facebook, twitter, photograph sharing website: flicker, photo bucket, video sharing: youtube, professional network website: linkedin, ning, blogs: blogger.com, wordpress, wikies: wet paint, pbwiki, content labeling: merlot, sloog, virtual word: sl, active worlds, there, whyville, club penguin, hipihi. In summary, digital content used under new media can also be referred to as social networking.

Facebook has not only increased the skills of people in establishing communication with each other but also collected in itself all categories of self communication, interpersonal communication, group communication and massive communication, which were categorized by Dimbleby and Burton (Tufan Yeniçıtı, 2016: 130). Facebook users may create profiles in which personal features like photographs, age, gender, educational status, interest areas are included, send messages that are open for everyone or that are private and join different friendship groups. Facebook has a feature that supports the interaction of its users (Tiryaki, 2015: 74).

According to Ellison et al., Facebook plays an important role in shaping and sustaining the social capitals especially of students (Köseoğlu, 2012: 62). Two people (A and B) have profiles on Facebook. According to Ackland (2013), Person A requests person B to become a Facebook friend and person $\mathrm{B}$ accepts the friendship request.

Person A requests friendship

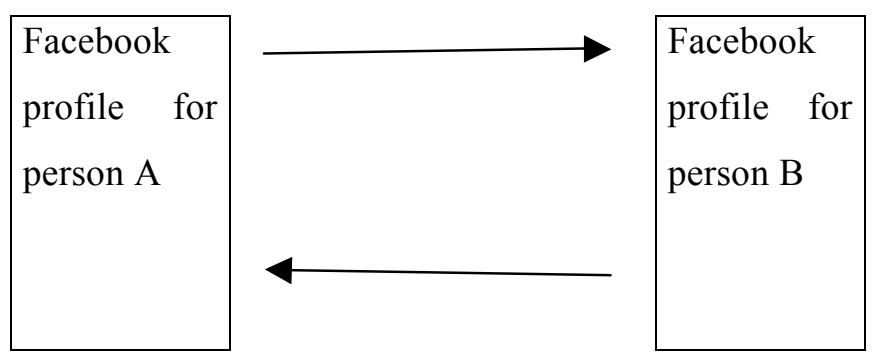

Person B accepts friendship request

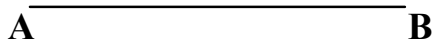

Figure 2. Facebook Network (Ackland, 2013).

Reasons for using Twitter (Solmaz et al., 2013: 25); Chat and dialogue feature (like short talk on telephone, but not dependent on one single man or on webpage interface), Enabling cooperation and exchange (for certain users), Enabling self-expression and self-communication (like blogging), Updating and checking status, Sharing information and news, Marketing and advertising (depending on location, interest areas and links). 
Thus we can represent this example multiplex Twitter network as a directed and unweighted simplex network with person A nominating person B, and person C nominating person B (Figure 3) (Ackland, 2013: 65).

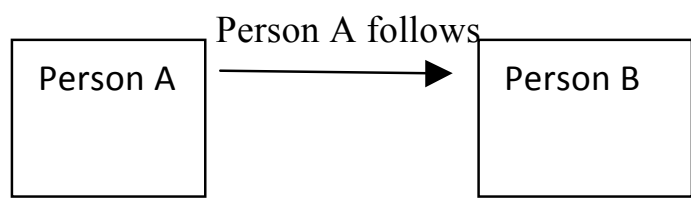

Person B
Person C mentions Person B

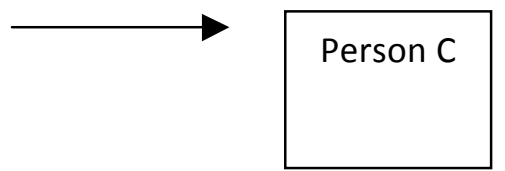

in tweet

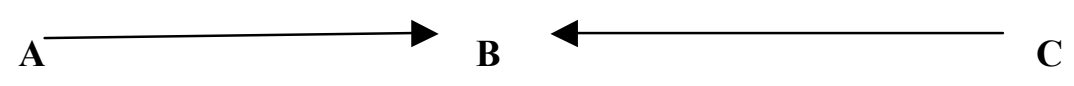

Figure 3. Twitter Network (Ackland, 2013).

\section{THE STUDY}

The Purpose of the Study: The study makes scientific evaluations and interpretations on the use of social media, which is hypothesized to be used and perceived most frequently by university students as a new communication means with the data like age, gender, department and grades of students to investigate whether there is a relation among these variables. The Importance of the Study: The study is important in that it investigates the variables like age, gender, department studies, and grades of university students are effective on determining the social media use tendencies and determines the social media awareness levels.

The Limitations of the Study: The study was limited with the students of Erzincan Binali Yildirım University, Education Faculty, Class Teachers Department, Computer and Teaching and Training Technologies (BOTE), Psychological and Guidance (PDR) and Primary School Mathematics Teaching. The study was conducted merely with questionnaires, and no face-to-face interviews were made. The Universe and Sampling of the Study: The study was conducted with 233 students at Erzincan Binali Yıldırım University, Education Faculty. A total of 20 questionnaires were excluded from the analyses because of being empty and not easy to analyze. The analyses and evaluations were made with 213 students 142 of whom were female, and 71 of whom were male.

The Method of the Study: The data of the study were collected with questionnaire method. The study was a quantitative study, and the screening model was employed in it. After the study data were transferred to the computer medium, missing data and edge value analyses were made, and the normality of the dataset was examined. For this purpose, the Kolmogorov-Smirnov test and Histogram Graphics were made use of, and it was determined that the dataset had a parametric quality. Finally, the Levene Homogeneity values were examined. After this stage, the t-test and the One-Way Variance Analysis (ANOVA) were used for independent samplings in the analysis of the sub-problems for which answers were sought. The SPSS 21.00 program was used in data analysis.

\section{The Findings of the Study and Evaluation:}

Whether the social media use tendencies of the students showed significant differences according to some variables was analyzed, and the findings are reported below.

Sub-problem 1. Do social media use tendencies of the students differ at a significant level according to their genders? 
To determine whether the social media use tendencies of the students differed according to the gender variable, the independent samples t-test was applied. In this context, firstly, the Levene Homogeneity Test was applied to test whether the dataset had parametric value or not, and the following was found $\mathrm{F}=.438, \mathrm{p}>.05$. The finding was evaluated as the dataset ensured the homogeneity, which is one of the parametric conditions of the dataset.

Table 1. Findings on the Gender Variable.

\begin{tabular}{|l|l|l|l|l|l|l|}
\hline & Gender & $\mathbf{N}$ & $\mathbf{X}$ & SD & $\mathbf{t}$ & $\mathbf{p}$ \\
\hline $\begin{array}{l}\text { Social media use } \\
\text { tendencies }\end{array}$ & Female & 142 & 39,7762 & 4,50730 & & \\
\cline { 2 - 6 } & Male & 71 & 38,0141 & 3,71288 & & .00 \\
\hline
\end{tabular}

When Table 1 is examined, it is seen that the social media use tendencies of the students differ at a significant level according to the gender variable $\left(\mathrm{F}_{212}=2.84 ; \mathrm{p}<.05\right)$. When the average scores are considered, it is possible to claim that the social media use tendencies of female students were higher at a significant level compared to those of male students; and in this respect, it is also possible to claim that the gender variable is a factor that affects the social media use tendencies.

Sub-problem 2. Do social media use tendencies of the students differ at a significant level according to their ages?

One-Way Variance Analysis was applied to determine whether the social media use tendencies of the students differed according to the age variable. In this context, firstly, the Levene Homogeneity Test was applied to test whether the dataset had parametric value or not, and the following was found $\mathrm{F}=.213 ; \mathrm{p}>.05$. The finding was evaluated as the dataset ensured the homogeneity, which is one of the parametric conditions of the dataset.

Table 2. Findings on the age Variable.

\begin{tabular}{|c|c|c|c|c|c|c|c|}
\hline & Age & $\mathbf{N}$ & $\mathbf{X}$ & SD & $\mathbf{F}$ & $\mathbf{p}$ & $\begin{array}{l}\text { Source of the } \\
\text { Difference }\end{array}$ \\
\hline \multirow[t]{4}{*}{$\begin{array}{l}\text { Social media use } \\
\text { tendencies }\end{array}$} & $\begin{array}{ll}\text { Below } & 18 \\
\text { years } & \text { of } \\
\text { age } & \end{array}$ & 19 & 27,6316 & 41,90096 & \multirow[t]{4}{*}{10,90} & \multirow[t]{4}{*}{.00} & \multirow[t]{4}{*}{$\begin{array}{l}\mathrm{A}<\mathrm{B}, \mathrm{A}<\mathrm{C} \\
\mathrm{D}<\mathrm{B}, \mathrm{D}<\mathrm{C}\end{array}$} \\
\hline & $19-22$ & 121 & 63,3435 & 31,40058 & & & \\
\hline & $23-26$ & 55 & 61,0678 & 41,26611 & & & \\
\hline & $\begin{array}{ll}\text { Above } & 26 \\
\text { years } & \text { of } \\
\text { age } & \end{array}$ & 18 & 24,5000 & 40,85736 & & & \\
\hline
\end{tabular}

$\mathrm{A}=$ Below 18 years of age, $\mathrm{B}=18-22$ age, $\mathrm{C}=23-26$ age, $\mathrm{D}=$ Above 26 years of age.

When Table 2 was examined, it was determined that the social media use tendencies of the students differed at a significant level according to the age variable $\left(\mathrm{F}_{209}=10,90 ; \mathrm{p}<.05\right)$. In this context, as a result of the Tukey Test, which was made to determine the source of the difference between the average values, it was determined that the average scores of the social media users below the age of 18 were lower compared to those between 19-22 years of age and 23-26 years of age; and that the average scores of those above 26 years of age were lower at a significant level compared to those between 1822 years of age, and 23-26 years of age.

In the light of the finding, it may be concluded that the age variable was effective on social media use of the participating students. 
Sub-problem 3. Do social media use tendencies of the students differ at a significant level according to their departments they study?

To determine whether the social media use tendencies of the students differed according to the department variable, the One-Way Variance Analysis was applied. In this context, firstly, the Levene Homogeneity Test was applied to test whether the dataset had parametric value or not, and the following was found $\mathrm{F}=.312, \mathrm{p}>.05$. The finding was evaluated as the dataset ensured the homogeneity, which is one of the parametric conditions of the dataset.

Table 3. Findings on the Department Variable.

\begin{tabular}{|l|l|l|l|l|l|l|}
\hline & Department & $\mathbf{N}$ & $\mathbf{X}$ & SD & F & p \\
\hline \multirow{2}{*}{$\begin{array}{l}\text { Social media } \\
\text { use }\end{array}$} & PDR & 53 & 38,8868 & 4,93286 & & \multirow{3}{*}{.86} \\
\cline { 2 - 6 } tendencies & BOTE & 59 & 39,5763 & 4,57581 & .320 & \multirow{2}{*}{.82207} \\
\cline { 2 - 6 } & MATHEMATICS & 50 & 39,2200 & 4,12207 & & \\
\cline { 2 - 6 } & GRADE & 51 & 39,0980 & 3,63458 & & \\
\hline
\end{tabular}

When Table 3 is examined, it is seen that the social media use tendencies of the students did not differ according to their departments $\left(\mathrm{F}_{209}=.320 ; \mathrm{p}>.05\right)$. In the light of these findings, it may be claimed that the departments of the students was not a variable that affected the social media use tendencies.

Sub-problem 4. Do social media use tendencies of the students differ at a significant level according to their grades?

The One-Way Variance Analysis was applied to determine whether the social media use tendencies of the students differed at a significant level according to the grades of the students. In this context to determine whether the social media use tendencies of the students differed according to the gender variable, the independent samples t-test was applied. In this context, firstly, the Levene Homogeneity Test was applied to test whether the dataset had parametric value or not, and the following was found $\mathrm{F}=.975, \mathrm{p}>.05$. The finding was evaluated as the dataset ensured the homogeneity, which is one of the parametric conditions of the dataset.

Table 4. Findings on Grade Variable.

\begin{tabular}{|c|c|c|c|c|c|c|c|}
\hline & Grade & $\mathbf{N}$ & $\mathbf{X}$ & SD & $\mathbf{F}$ & p & $\begin{array}{l}\text { Source of } \\
\text { Difference }\end{array}$ \\
\hline \multirow{4}{*}{$\begin{array}{l}\text { Social media } \\
\text { use tendencies }\end{array}$} & 1. Grade & 53 & 17,45 & 4,16 & \multirow{4}{*}{4,76} & \multirow{4}{*}{.00} & \multirow{4}{*}{$\begin{array}{l}\mathrm{A}<\mathrm{B}, \mathrm{A}<\mathrm{C} \\
\mathrm{D}<\mathrm{B}, \mathrm{D}<\mathrm{C}\end{array}$} \\
\hline & 2. Grade & 59 & 24,46 & 3,14 & & & \\
\hline & 3. Grade & 50 & 25,13 & 4,21 & & & \\
\hline & 4. Grade & 51 & 16,85 & 4,05 & & & \\
\hline
\end{tabular}

When Table 4 is examined it is seen that the social media use tendencies of the students differ at a significant level according to the grade of the students $\left(\mathrm{F}_{209}=4,76, \mathrm{p}<.05\right)$. In this context, as a result of the Tukey Test, which was made to determine the source of the difference between the averages of the students, it was determined that the social media use tendencies of $1^{\text {st }}$ grade students and $4^{\text {th }}$ grade students were lower than those of the $2^{\text {nd }}$ and $3^{\text {rd }}$ graders. In the light of the findings obtained in the study, it is possible to claim that the grade variable is a variable that affects the social media use tendencies of the students. 


\section{RESULTS}

Towards the year 2000, global village, globalization, information society, internet technology, new basic technologies, competition environment, etc. came into prominence. The first quarter of the $21^{\text {st }}$ century came to the fore as electronic and digital age. New media technologies are one of the most important elements of the digital and electronic age. Social media is the most important element of the new media. social media is a very large platform with millions of users. Social media has an important place in the lives of university students as a new communication an media. Social media use tendencies have become one of the most important parameters affecting the lives of university students. Therefore, there is a need for research on trends in social media usage. In this study, the data on the extent to which demographic variables affect university students' tendency to use social media have been revealed. From this point, the research is important in this aspect.

After the analyses of the data obtained in the present study, the following results were obtained. In the evaluations that were made in the context of the gender variable, it may be claimed that woman students have significantly higher scores in social media use tendencies than male students; and therefore, the gender variable is a factor that differentiates social media use tendencies of the students. In the context of the age, it was determined that the average social media tendency scores of those who were under 18 years of age were significantly lower than the users of the age group 19-22 and 23-26; and the average scores of the users who were over the age of 26 were significantly lower than those of the 18-22 and 23-26 age group, and that the age can be evaluated as a variable affecting social media use tendencies. When the students are evaluated according to their department, social media use tendencies did not show a significant difference according to this variable, and it may be evaluated that the department is not a that affected social media use tendencies. In the evaluation that was made according to the Grades of the students, it may be evaluated that the $1^{\text {st }}$ Graders and $4^{\text {th }}$ Graders had lower scores than the social media use tendencies of the $2^{\text {nd }}$ and $3^{\text {rd }}$ Grade students; and therefore, it may be claimed that the Gradevariable is a variable affecting social media use tendencies.

\section{REFERENCES}

Ackland, R. (2013). Web Social Science, Los Angeles, London, New Delhi, Singapore, Washington DC: SAGE Publications.

Aktan, C.C. (2007). Change in Higher Education: Global Trends and New Paradigms, Can Coşkun Aktan, Higher Education in Change Age, Izmir: Yaşar University Publication.

Çetintaş, H.B. (2014). Corporate Communication Strategy and Corporate Blogs, Konya: Education Publication.

Dijilopedi. (2018). "Digital in 2018 in Western Asia" Research, https://dijilopedi.com/2018-turkiyeinternet-kullanim-ve-social-medya-istatistikleri/ (access date: 02.09.2019).

Ertekin, İ. (2019). A Social Media Research in terms of Variables, Turkish Studies, 14 (2), 385-399.

Hinton, H. and Hjorth, L. (2013). Understanding Social Media, Los Angeles, London, New Delhi, Singapore, Washington DC: SAGE Publications.

Kahraman, M. (2013). Social Media 101 2.0, Istanbul: MediaCat Publications.

Köseoğlu, Ö. (2012). Social Network Website Users' Motivations: A Research on Facebook, Seljuk Communication Journal, 7(2), 58-81.

Kotler, P. (2010). Marketing from A to Z, Istanbul: MediaCat Publications.

McLuhan, M. and Powers, B.R. (2001). Global Village (Translated by Bahar Öcal Düzgören), Istanbul: Scala Publication.

Smith, P. R. and Zook, Z. (2011). Marketing Communications: Integrating Offline and Online with Social Media, London: Kogan Page Limited. 
Solmaz, B., Tekin, G., Herzem, Z and Demir, M. (2013). An Application on Internet and Social Media Use, Seljuk Communication Journal, 7(4), 23-32.

Tesla, N. (2015). The Unbearable Weight of Existence: Aphorisms (Translated by P. Demirel), Istanbul: Aylak Adam Culture and Art Publication.

Tiryaki, S. (2015). Facebook Addiction in Social Life: A Field Study in Konya Sample, Unpublished Doctorate Thesis, Konya: Selçuk University, Graduate School of Social Sciences.

Tufan Yeniçıktı, N. (2016). Social Media Usage Motivations: A Research on Facebook and Twitter Users and Satisfactions, Unpublished Doctorate Thesis, Konya: Selçuk University, Graduate School of Social Sciences.

Tutar, H. and Y1lmaz, M.K. (2005). Communication with General and Organizational Dimensions, Ankara: Seçkin Publication.

Vural, Z. B. A. and Bat, M. (2010). "Social Media as a New Communication Medium: A Study on Ege University, Communication Faculty", Journal of Yaşar University, 20 (5), 33483382.

Yengin, D. and Bayrak, T. (2018). Increased Reality with the Maturation of Consumption, Interaction Journal, 1(1), 56-77. 